\title{
Lower Ordovician conodonts from Washington Land, western North Greenland
}

\author{
SVEND STOUGE, GABRIELLA BAGNOLI STOUGE, ROBERTO ALBANI
}

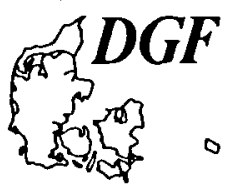

\begin{abstract}
Stouge, S., Stouge, G. B. and Albani, R.: Lower Ordovician conodonts from Washington Land, western North Greenland. Bull. geol. Soc. Denmark, vol. 33, pp. 261-272, Copenhagen, February, 28th, 1985.

Early Canadian (Lower Ordovician) conodonts have been recorded from loose slabs which were collected by J. C. Troelsen in 1941 at Kap Clay, Washington Land, western North Greenland. The samples probably derived from the Cape Clay Formation which is exposed in the steep coastal cliff. The macrofauna of the samples includes Symphysurina sp. of Early Ordovician age. The conodont fauna comprises "Paltodus" bassleri Furnish, Utahconus oneotensis (Furnish), "Oistodus" triangularis Furnish, and species of Cordylodus Pander and "Acontiodus" Pander. The fauna correlates with Fauna C of the North American Midcontinental Faunal succession and with the Cordylodus angulatus Zone of the Baltic-Scania succession. Locally, it correlates with the conodont fauna recorded from the Cape Clay formation of Southern Devon Island, Canadian Arctic Archipelago.

The conodont fauna is described applying multielement taxonomy. In all 314 specimens, representing 20 multielement species, were recorded. Some species are new, but they are referred to only in open nomenclature because of the unsettled stratigraphical status of the loose blocks.
\end{abstract}

Svend Stouge, Institute of Historical Geology and Palaeontology, $\emptyset$ ster Voldgade 10, 1350 Copenhagen K, Denmark. Gabriella Bagnoli Stouge, Dipartimento di Scienze della Terra, Via S. Maria, 53, 56100 Pisa, Italy. Roberto Albani, Dipartimento di Scienze della Terra, Via S. Maria, 53, 56100 Pisa, Italy. June 16th, 1984.

\section{Introduction}

Preliminary mapping of the western part of North Greenland (Fig. 1) and reconnaissance work in various part of Ellesmere Island, Arctic Canada was undertaken by J. C. Troelsen (1950). He worked in the field in 1939-1941 as a member of the Danish Thule-Ellesmere Land Expedition. In this remote area the use of dog sledge was necessary and hence fieldwork was restricted to the periods from march to early june and from october to november, where ice conditions were favourable.

Previous to and during the years 1939-1941 mapping was hampered by the lack of basic topographical maps and often only the outline drawings of the coastline existed. The first geological map was published by Poulsen (1927). This was followed by geological maps presented by Koch $(1932,1933)$. At that time the CambroOrdovician succession was known only sporadically. The stratigraphy established by Poulsen (1927) and Koch (1929a, b) formed the basis for a preliminary division of the sediments which Troelsen (1950) adopted with modifications. De- spite the severe working conditions and the little information available Troelsen (1950) provided much new information and added greatly to the knowledge of the area (Fig. 2).

Later Dawes $(1971,1976)$ did geological reconnaissance work in North Greenland, and Henriksen \& Peel (1976) continued with establishing a reference section of the Cambro-Ordovician succession for the area. Since then a mapping project by the Geological Survey of Greenland produced major stratigraphical changes which had influence on the divisions of Poulsen (1927), Koch (1929a, b), and Troelsen (1950). In addition a similar project on the Canadian side by the Geological Survey of Canada will certainly increase the knowledge of the Paleozoic stratigraphy in the North Greenland-Canadian Arctic Region.

\section{Geological setting}

The sequence in western North Greenland rests upon the Precambrian crystalline basement which is ovelain by autochthonous Proterozoic to 


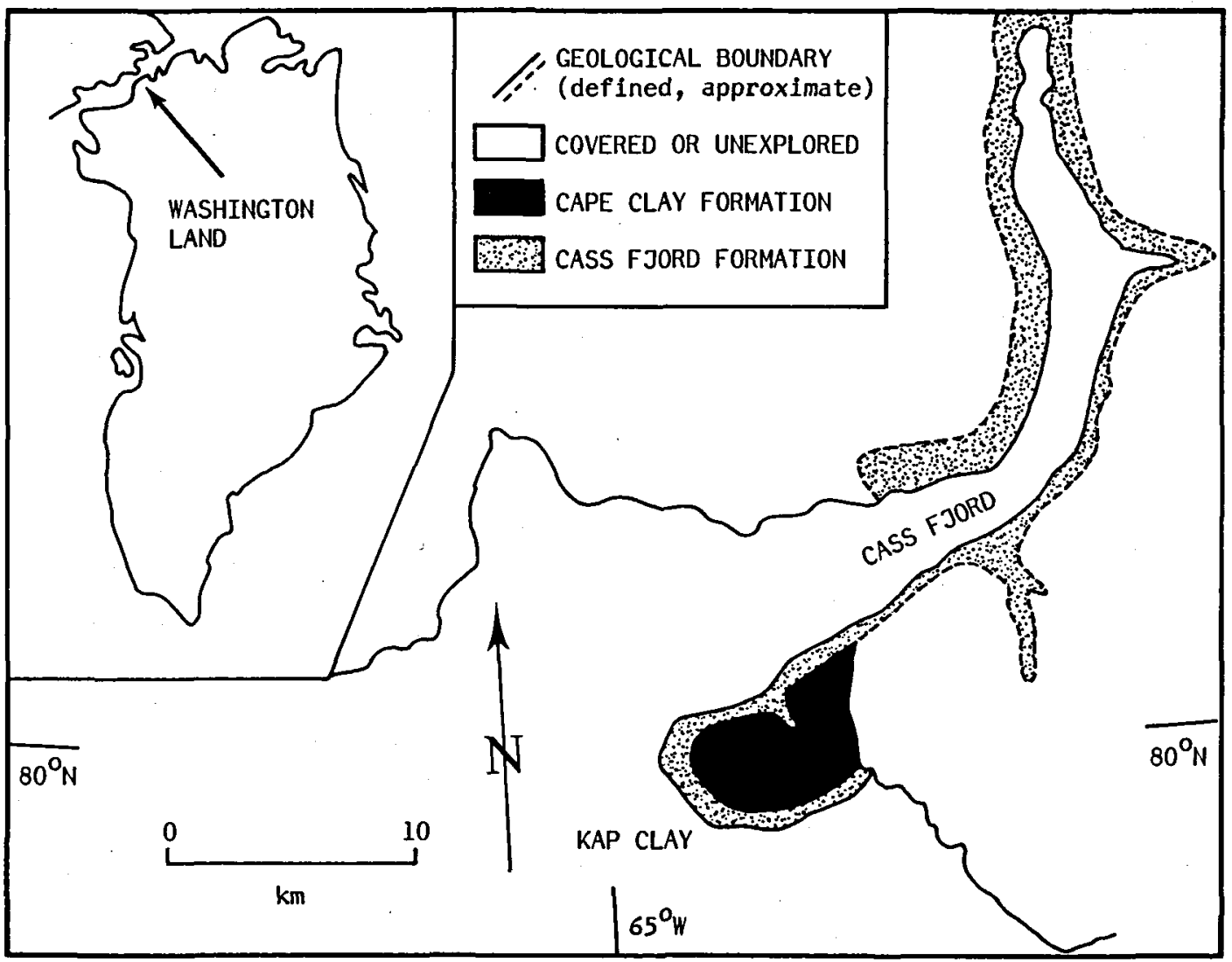

Figure 1. Location map of the Kap Clay area, Washington Land, western North Greenland. (Modified from Troelsen (1950). For new information on the geology, see Henriksen \& Peel (1976)).

Lower Palaeozoic sediments with a marked angular unconformity. The sediments occur in a wide east-west trending belt and dip towards north forming a platform in front of the North Greenland foldbelt (Dawes 1976). The North Greenland foldbelt is a continuation of the Franklinian foldbelt in the Arctic Canada.

The Lower Palaeozoic in North Greenland is represented by platform carbonates, evaporites and shales. The Silurian strata include a giant reef complex (Hurst \& Surlyk 1983) that also developed across Arctic Canada.

\section{Cape Clay Formation}

Poulsen (1927) and Koch (1929a, b) introduced the Cape Clay Formation based on the succession at the Kap Clay cliff in Washington Land, western North Greenland (Fig. 1). This term was adopted also for Ellesmere Island (Troelsen 1950; Christie 1967). Koch (1929a, b) and Troelsen (1950) were unable to define the lower and upper boundaries of the Cape Clay Formation, because of deep snow at the time of their visit.

Henriksen \& Peel (1976) reexamined the area at Kap Clay and established the stratigraphic boundaries of the Cape Clay Formation.

The Cape Clay Formation conformably overlies the Cass Fjord Formation (Upper CambrianLower Ordovician) and it is in turn overlain by the Lower Ordovician Christian Elv Formation (Henriksen \& Peel 1976) (Fig. 2). The formation is reported to be 50 metres thick. The lithologies include bedded, yellow, dolomitic biomicrite and biosparite. The trilobites Hystricurus and Symphysurina suggest an Early Canadian age (Lower Ordovician) (Poulsen 1927). Conodonts have previously been referred to Fauna $C$ of the North American conodont succession (Kurtz 1977; 


\begin{tabular}{|c|c|c|c|c|}
\hline 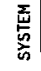 & 苌 & $\begin{array}{l}\text { Poul sen }(1927) \\
\text { Koch }(1929 \mathrm{a}, \mathrm{b})\end{array}$ & $\begin{array}{l}\text { Troelsen } \\
\text { (1950) }\end{array}$ & $\begin{array}{l}\text { Henriksen \& } \\
\text { Peel (1976) }\end{array}$ \\
\hline \multirow{5}{*}{ 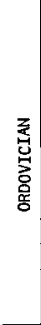 } & \multirow{5}{*}{ 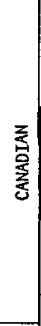 } & \multirow{2}{*}{$\begin{array}{l}\text { MunatamL } \\
\text { Fm }\end{array}$} & \multirow{2}{*}{$\begin{array}{c}\text { Poulsen Cliff } \\
\text { Fm }\end{array}$} & $\begin{array}{c}\text { Poulsen cliff } \\
\mathrm{Fm}\end{array}$ \\
\hline & & & & $\begin{array}{c}\text { Christian Elv } \\
\text { Fm }\end{array}$ \\
\hline & & $\begin{array}{c}\text { CAPE CLAY } \\
\mathrm{Fm}_{\mathrm{m}}\end{array}$ & CAPE CLAY & $\underset{\mathrm{Fm}}{\text { CAPE }}$ \\
\hline & & Cass Fjord Fm & Cass $\mathrm{Fford} \mathrm{Fm}$ & \multirow[t]{2}{*}{ Cass $\mathrm{Fford} \mathrm{Fm}$} \\
\hline & & (H1atus) & (Hiatus) & \\
\hline
\end{tabular}

Figure 2. History of Lower Ordovician lithological units from Washington Land, western North Greenland and development of ideas. Data from Poulsen (1927), Koch (1929a, b), Troelsen (1950) and Henriksen \& Peel (1976).

Stouge 1977). In the present samples Symphysurina sp. has been recorded (C. Poulsen pers. comm. 1971).

\section{Conodont samples and fauna}

Troelsen collected fossiliferous samples, not in situ, but from the talus beneath the coastal cliff at
Kap Clay, Washington Land, western North Greenland (Fig. 1). It is likely, however, that the samples derived from the Early Ordovician Cape Clay Formation (C. Poulsen pers. comm. 1971; Stouge 1977). The present paper describes the conodont fauna which was recovered from the chips of the fossiliferous samples.

Troelsen labeled the samples no. 463 to 480 , $26 / 41941$. Of these no. 465,470 and 472 were not processed. Except for samples no. 474 and 476, all processed samples yielded conodonts and in some cases in a relatively high number (Table 1 ).

The conodonts are resonably well preserved with a CAI (Conodont Alteration Index of Epstein, Epstein \& Harris 1977) of 1 which suggests that the host rock has not been severely affected by heat $\left(50^{\circ} \mathrm{C}-60^{\circ} \mathrm{C}\right)$. The conodonts are recrystallized and have a sucrose surface. Several specimens have secondary crystal faces on the surface and at some simple cone elements the cross-section of the cusp has been slightly modified from oval to rhomboedric.

Many of the simple conodont elements are very small and morphological details, such as keels, carinae and costae are best recognized in the SEM. Also the secondary recrystallized specimens with a modified cusp morphology are best distinguished in the SEM.

Table 1. Occurrence of conodonts from productive samples at Kap Clay, Washington Land, western North Greenland.

\begin{tabular}{|c|c|c|c|c|c|c|c|c|c|c|c|c|c|c|}
\hline Sample numbers & 463 & 464 & 466 & 467 & 468 & 469 & 471 & 473 & 475 & 477. & 478 & 479 & 480 & Total \\
\hline $\begin{array}{l}\text { SPECIES } \\
\text { "Acontiodus" iowensis } \\
\text { "Acontiodus" propinquus } \\
\text { "Acontiodus" staufferi } \\
\text { "Acontiodus" aff. latus } \\
\text { Cordylodus angulatus } \\
\text { Cordylodus caboti } \\
\text { Cordylodus deflexus. } \\
\text { Cordylodus intermedius } \\
\text { Cordylodus proavus } \\
\text { Cordylodus subangulatus } \\
\text { Clavohamulus sp. A } \\
\text { Cornuodus sp. A } \\
\text { Drepanoistodus sp. } \\
\text { "Oistodus" triangularis } \\
\text { "Paltodus" bassleri } \\
\text { Utahconus oneotensis } \\
\text { U. aff. oneotensis } \\
\text { Gen. et sp. indet. A } \\
\text { Gen. et sp. indet. B } \\
\text { Gen. et sp. indet. C }\end{array}$ & $\begin{array}{l}3 \\
- \\
- \\
- \\
- \\
- \\
- \\
- \\
- \\
- \\
- \\
2 \\
- \\
- \\
1 \\
5 \\
- \\
2 \\
2 \\
-\end{array}$ & $\begin{array}{c}2 \\
- \\
- \\
- \\
- \\
3 \\
6 \\
8 \\
3 \\
- \\
- \\
3 \\
- \\
2 \\
6 \\
15 \\
- \\
7 \\
3 \\
2\end{array}$ & $\begin{array}{l}- \\
1 \\
1 \\
- \\
- \\
- \\
1 \\
- \\
- \\
- \\
1 \\
- \\
- \\
1 \\
1 \\
3 \\
- \\
- \\
- \\
-\end{array}$ & $\begin{array}{l}1 \\
- \\
- \\
- \\
-1 \\
1 \\
- \\
- \\
- \\
- \\
1 \\
- \\
- \\
- \\
- \\
- \\
- \\
-\end{array}$ & $\begin{array}{l}1 \\
- \\
- \\
1 \\
2 \\
4 \\
2 \\
6 \\
- \\
- \\
4 \\
3 \\
1 \\
1 \\
3 \\
3 \\
3 \\
4 \\
1 \\
3\end{array}$ & $\begin{array}{l}1 \\
- \\
- \\
- \\
- \\
4 \\
1 \\
2 \\
- \\
1 \\
- \\
2 \\
- \\
- \\
1 \\
1 \\
- \\
1 \\
2 \\
2\end{array}$ & $\begin{array}{l}- \\
- \\
1 \\
- \\
- \\
4 \\
2 \\
4 \\
- \\
- \\
3 \\
3 \\
- \\
1 \\
1 \\
3 \\
1 \\
- \\
4 \\
-\end{array}$ & $\begin{array}{c}1 \\
- \\
- \\
- \\
- \\
- \\
5 \\
1 \\
- \\
- \\
6 \\
- \\
1 \\
- \\
- \\
12 \\
1 \\
- \\
1\end{array}$ & $\begin{array}{l}1 \\
- \\
1 \\
- \\
1 \\
2 \\
- \\
2 \\
- \\
- \\
- \\
1 \\
- \\
- \\
2 \\
1 \\
- \\
4 \\
- \\
-\end{array}$ & $\begin{array}{l}- \\
1 \\
1 \\
- \\
- \\
- \\
1 \\
- \\
1 \\
- \\
- \\
11 \\
- \\
- \\
4 \\
7 \\
2 \\
- \\
4 \\
2\end{array}$ & $\begin{array}{l}- \\
- \\
- \\
- \\
2 \\
1 \\
5 \\
2 \\
3 \\
- \\
- \\
- \\
- \\
2 \\
3 \\
17 \\
- \\
4 \\
- \\
-\end{array}$ & $\begin{array}{l}- \\
- \\
- \\
- \\
- \\
1 \\
- \\
- \\
2 \\
- \\
1 \\
- \\
- \\
- \\
2 \\
2 \\
- \\
4 \\
3\end{array}$ & $\begin{array}{l}- \\
- \\
- \\
- \\
- \\
1 \\
- \\
1 \\
- \\
- \\
3 \\
- \\
- \\
- \\
- \\
1 \\
- \\
- \\
- \\
-\end{array}$ & $\begin{array}{r}10 \\
2 \\
4 \\
2 \\
5 \\
21 \\
24 \\
26 \\
9 \\
1 \\
18 \\
26 \\
2 \\
7 \\
24 \\
71 \\
7 \\
26 \\
20 \\
9\end{array}$ \\
\hline $\begin{array}{l}\text { Weight of samples } \\
\text { (gms.) }\end{array}$ & 185 & 276 & 75 & 210 & 345 & 85 & 330 & 145 & 115 & 140 & 200 & 95 & 165 & 314 \\
\hline
\end{tabular}


Age of the conodont fauna

The Kap Clay conodont fauna is biostratigraphically characterized by species of the multielement genus Cordylodus Pander. Simple cones are relatively most abundant and among those Utahconus oneotensis (Furnish) is the most frequent.

The fauna comprises elements which usually are referred to the Midcontinent Province, but Cordylodus is also characteristic in the North Atlantic Faunal Province (Sergeeva 1963; Lindström 1971; van Wamel 1974; Viira 1974).

In North America Cordylodus intermedius Furnish and Cordylodus angulatus Pander are important, because they occur together in the Lower Ordovician Fauna C (Ethington \& Clark 1971) or in the Loxodus bransoni Interval (Ethington \& Clark 1981) of the North American conodont faunal succession. Loxodus bransoni is the key species for the Loxodus bransoni Interval, but has not been recorded in the Kap Clay material. Utahconus oneotensis, however, which is present in all of the Kap Clay samples, first appears within the Loxodus bransoni Interval, where it is associated with Cordylodus angulatus. Thus a correlation with the Loxodus bransoni Interval is suggested for the Kap Clay material. The other Kap Clay species are consistent with this age assignment.

In the Lower Ordovician of the Baltic-Scania area Cordylodus intermedius and Cordylodus angulatus occur together in the Cordylodus angulatus Zone (Tremadocian) of the North Atlantic Faunal Province.

The composition of the Kap Clay conodont fauna from Washington Land, western North Greenland is similar to the association described by Landing \& Barnes (1981) from the Cape Clay Formation, southern Devon Island, Arctic Archipelago, Canada.

\section{Systematic Palaeontology}

In this paper the multielement approach is applied where it is possible. When referring to an original single-element-based taxon we follow the recommendations of Jeppsson \& Merrill (1982) by using sensu, the name of the author and the year.
The following species are illustrated but not described because either they occur in sufficient number to allow new taxonomic interpretation or have been discussed elsewhere and are not dealt with further in this section.

“Acontiodus" iowensis Furnish (PI. 1, Figs 1, 3). "Acontiodus" propinquus Furnish (Pl. 1, Fig. 2). "Acontiodus" staufferi Furnish (PI. 1, Fig. 4). "Acontiodus" aff. "A." latus Pander (Pl. 1, Fig. 5).

Cordylodus angulatus Pander (PI. 1, Figs. 6-7; Text-fig. 3J, K).

Cordylodus caboti Bagnoli, Barnes \& Stevens (Pl. 1, Figs. 8-10; Text-fig. 3C, L).

Cordylodus deflexus Bagnoli et al. (Pl. 1, Figs. 11, 12; Text-fig. 3C, L).

Cordylodus intermedius Furnish (Pl. 1, Figs. 1315; Text-fig. 3G, H, I).

Cordylodus proavus Müller (Pl. 1, Figs. 16, 18; Text-fig. 3A, B).

Cordylodus subangulatus Furnish (Pl. 1, Fig. 17).

We follow the interpretation of Ethington \& Clark (1981) for the genus "Acontiodus" Pander and the interpretation of Bagnoli, Barnes \& Stevens (in press) for the species of the multielement genus Cordylodus Pander.

All the illustrated elements are deposited at the Mineralogical Museum, Copenhagen (MGUH).

Genus Clavohamulus Furnish, 1938.

Type species - Clavohamulus densus Furnish, 1938.

Clavohamulus sp. A. Pl. 2, Figs. 1-2.

Description - The elements of Clavohamulus sp. $A$ have a reduced bulb and in some specimens the bulb is barely seen. The basal cavity is very shallow and the tip is located anteriorly. The elements have white matter above the base. The cross section of the base varies from oval to rounded. The base is expanded posteriorly and a small flare which is located close to the aboral edge is present in large specimens.

Material - 18 specimens.

Repository - MGUH 16358-16359. 

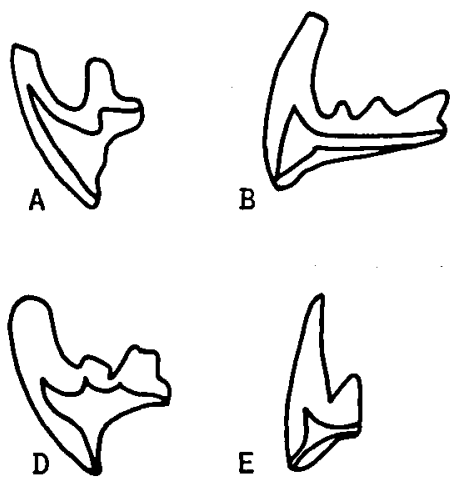

E

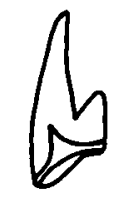

H
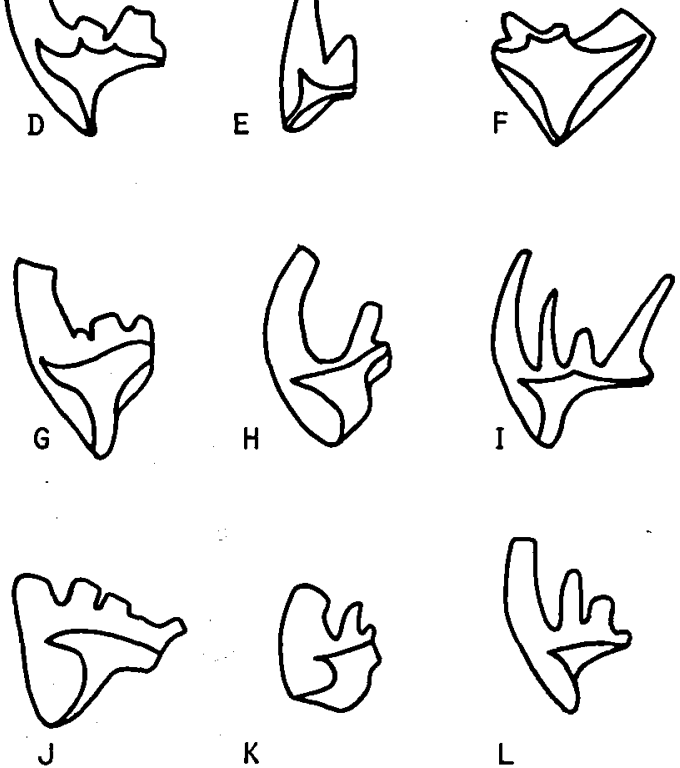

K

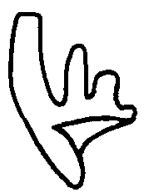

L

Figure 3. Lateral outlines and basal cavity silhouettes of Cordylodus species from Kap Clay, Washington Land, western North Greenland.

3A, B: Corcylodus proavus Müller sensu Bagnoli et al. 3A: cordylodontiform (= rounded; $p$ element), Sample 470, MGUH 16370, $\times 110$. 3B: cyrtoniodontiform (= compressed; q element), Sample 479, MGUH 16371, $\times 85$.

3C, L: Cordylodus deflexus Bagnoli et al. 3C: cyitoniodontiform (= compressed; q element), Sample 467, MGUH 16366, $\times 80$. 3L: cordylodontiform ( $=$ rounded; $p$ element), Sample 473, MGUH 16365, $\times 40$.

3D, E, F: Cordylodus caboti Bagnoli et al. 3D: cordylodontiform (= rounded; p element), Sample 464, MGUH 16363, $\times 75$. 3E: cyrtoniodontiform (= compressed; $q$ element), Sample 471, MGUH 16364, $\times 100$. 3F: cordylodontiform (= rounded; p element), Sample 468, MGUH 16362, $\times 40$.

3G, H, I: Cordylodus intermedius Furnish sensu Bagnoli et al. 3G: cordylodontiform (= rounded; p element), Sample 464, MGUH 16368, $\times 35$. 3H: cyrtoniodontiform (= compressed; $\mathrm{q}$ element), Sample 480, MGUH 16369, $\times 65$. 3I: cordylodontiform (= rounded; p element), Sample 478, MGUH 16367, $\times 40$.

3J, K: Cordylodus angulatusPander sensu Bagnoli et al. 3J: cordylodontiform ( $=$ rounded; $p$ element), Sample 478, MGUH $16360, \times 35$. 3K: cyrtoniodontiform (= compressed; q element), Sample 478, MGUH 16361, $\times 40$.

Genus Cornuodes Fåhræus, 1966.

Type species - Drepanodus longibasis Lindström, 1955.

Cornuodus sp. A. Pl. 2, Figs. 3-7.

Synonymy

?1970 Oneotodus altus sp.n. - Viira, p. 229-230, Pl. A, Fig. 10; Text-fig. 7.

?1974 Oneotodus altus Viira - Viira, p. 97-98, Pl. 1, Fig. 24; Text-figs. ?119, 120.

1981 Cornuodus longibasis (Lindström) - Landing \& Barnes, p. 1614, Pl. 2, Fig. 6.

Description - Cornuodus sp. A comprises proclined to suberect, symmetrical and asymmetrical, elements with a rounded to oval cross section. The base varies from short to long. The deep basal cavity has an anteromedian tip which is located at the maximum point of curvature of the elements. The elements are finely striated. White matter is confined to the cusp. The asymmetrical elements have an oval cross section.

Remarks - In this paper we assign to Cornuodus a species which Landing \& Barnes (1981) referred to Cornuodus longibasis (Lindström). Although the generic assignment may be correct, the species is not identical with the Baltic Cornuodus longibasis.

Löfgren (1978) fully described the apparatus of Cornuodus longibasis (Lindström). According to her (Löfgren 1978) Cornuodus includes symmetrical elements $\mathrm{A}$ and $\mathrm{B}$ and asymmetrical elements. In our material the symmetrical element $B$ is missing.

Cornuodus sp. A differs from C. longibasis by the lack of posterior costae on the symmetrical element (see Löfgren 1978); in Cornuodus sp. A the element is keeled.

It is possible that Oneotodus altus Viira belongs go this species. The Kap Clay specimens are very small which prohibits species identification.

Material - 26 specimens.

Repository - MGUH 16373-16377.

Genus Drepanoistodus Lindström, 1971.

Type species - Oistodus forceps Lindström, 1955.

Drepanoistodus sp. PI. 2, Fig. 8. 
Remarks - Only drepanodontiforms were recorded and a species determination is not possible, because the diagnostic oistodontiform is missing.

Material -2 specimens.

Repository - MGUH 16378.

Genus Oistodus Pander, 1956.

Type species - Oistodus lanceolatus Pander, 1856.

“Oistodus" triangulatus Furnish. PI. 2, Figs. 9-10.

\section{Synonymy}

1938 Oistodus? triangularis n.sp. - Furnish, pp. 330-331, Pl. 42, fig. 22; Text-fig. 1.

1981 "Oistodus" triangularis Furnish - Ethington \& Clark, pp. 70-71, Pl. 7, Figs. 15, 18, 22, 23.

1981 Utahconus? bassleri (Furnish) - Landing \& Barnes, pp. 1622, 1624 (pars), Pl. 1, Fig. 21; Text-fig. 3: 14 (only).

Remarks - We follow the interpretation of Ethington \& Clark (1981) for this species.

Material -7 specimens.

Repository - MGUH 16379-16380.

Genus Paltodus Pander, 1865.

Type species - Paltodus subaequalis Pander, 1856.

"Paltodus" bassleri Furnish. Pl. 2, Figs. 15-17.
Synonymy

1938 Paltodus bassleri n.sp. - Furnish, p. 331, Pl. 42, Fig. 1.

1938 Paltodus variabilis n.sp. - furnish, p. 331, Pl. 42, Figs. 9-10.

1971 Paltodus bassleri Furnish - Ethington \& Clark, p. 72, Pl. 2, Figs. 2, 4, 6.

?1971 Scolopodus asymmetricus Druce \& Jones - Jones, pp. 61-62, Pl. 5, Figs. 1, 2.

?1971 Scolopodus bassleri (Furnish) - Jones, pp. 62-63, Pl. 5, Figs. 3, 6; Pl. 9, Figs. 2, 3.

1977 Paltodus variabilis Furnish - Lindström, pp. 429-431, (pars), Paltodus - Pl. 1, Fig. 10 (only).

1981 "Paltodus" bassleri Furnish - Ethington \& Clark, pp. 74-75, Pl. 8, Figs. 11, 12.

1981 Utahconus? bassleri (Furnish) - Landing \& Barnes, pp. 1622-1624 (pars), Pl. 1, Figs. 9, 19, 22; Pl. 3, Fig. 14; Text-fig. 3: 10, 15 (only).

1982 Scolopodus bassleri Furnish - Repetski, pp. 37, Pl. 14, Fig. 12.

1983 Utahconus? bassleri (Furnish) - Landing, pp. 1181-1182 (pars).

Remarks - In this paper we adopt the concept of "Paltodus" bassleri Furnish sensu Ethington \& Clark, 1981 and Repetski, 1982. According to those authors Paltodus bassleri sensu Furnish, 1938 and Paltodus variabilis sensu furnish, 1938 are elements of the same apparatus forming a symmetry transition series.

Discussion - Sweet \& Bergström (1972) suggested that the formspecies Acodus oneotensis

PLATE 1.

Fig. 1. "Acontiodus" iowensis Furnish, posterior view, Sample 469, MGUH 16354, $\times 100$.

Fig. 2. "Acontiodus" propinquus Furnish, posterior view, Sample 466, MGUH 16355, ×125.

Fig. 3. "Acontiodus" iowensis Furnish, posterior view, Sample 463, MGUH 16353, ×125.

Fig. 4. "Acontiodus" staufferi Furnish, posterior view, Sample 466, MGUH 16356, $\times 80$.

Fig. 5. "Acontiodus" aff. "A." latus Pander, posterior view, Sample 467, MGUH 16357, $\times 60$.

Figs. 6-7. Cordylodus angulatus Pander. 6: p element, lateral view, Sample 478, MGUH 16360, $\times 50$. 7: q element, lateral view, Sample 478, MGUH $16361, \times 60$.

Figs. 8-10. Cordylodus caboti Bagnoli, Barnes \& Stevens. 8: p element, lateral view, Sample 464, MGUH 16363, $\times 115.9: p$ element, lateral view, Sample 468, MGUH 16362, $\times 60$. 10: q element, lateral view, Sample 471, MGUH 16364, $\times 150$.

Figs. 11-12. Cordylodus deflexus Bagnoli, Barnes \& Stevens. 11: p element, lateral view, Sample 473, MGUH 16365, ×60. 12: q element, lateral view, Sample 467, MGUH 16366, $\times 120$.

Figs. 13-15. Cordylodus intermedius Furnish. 13: p element, lateral view, Sample 464, MGUH 16368, $\times 50.14:$ q element, lateral view, Sample 480, MGUH 16369, $\times$ 100. 15: p element, lateral view, Sample 478, MGUH 16367, $\times 60$.

Figs. 16, 18. Cordylodus proavus Müller. 16: p element, lateral view, Sample 470, MGUH 16370, ×170. 18: q element, lateral view, Sample 479, MGUH 16371, $\times 125$.

Fig. 17. Cordylodus subangulatus Furnish, lateral view, Sample 469, MGUH 16372, $\times 65$.

Figs. 19-21. Gen. et sp. indet. A. 19: lateral view, Sample 475, MGUH 16393, $\times 40$. 20: postero-lateral view, Sample 479, MGUH 16392, $\times 60$. 21: lateral view, Sample 464, MGUH 16391, $\times 125$. 


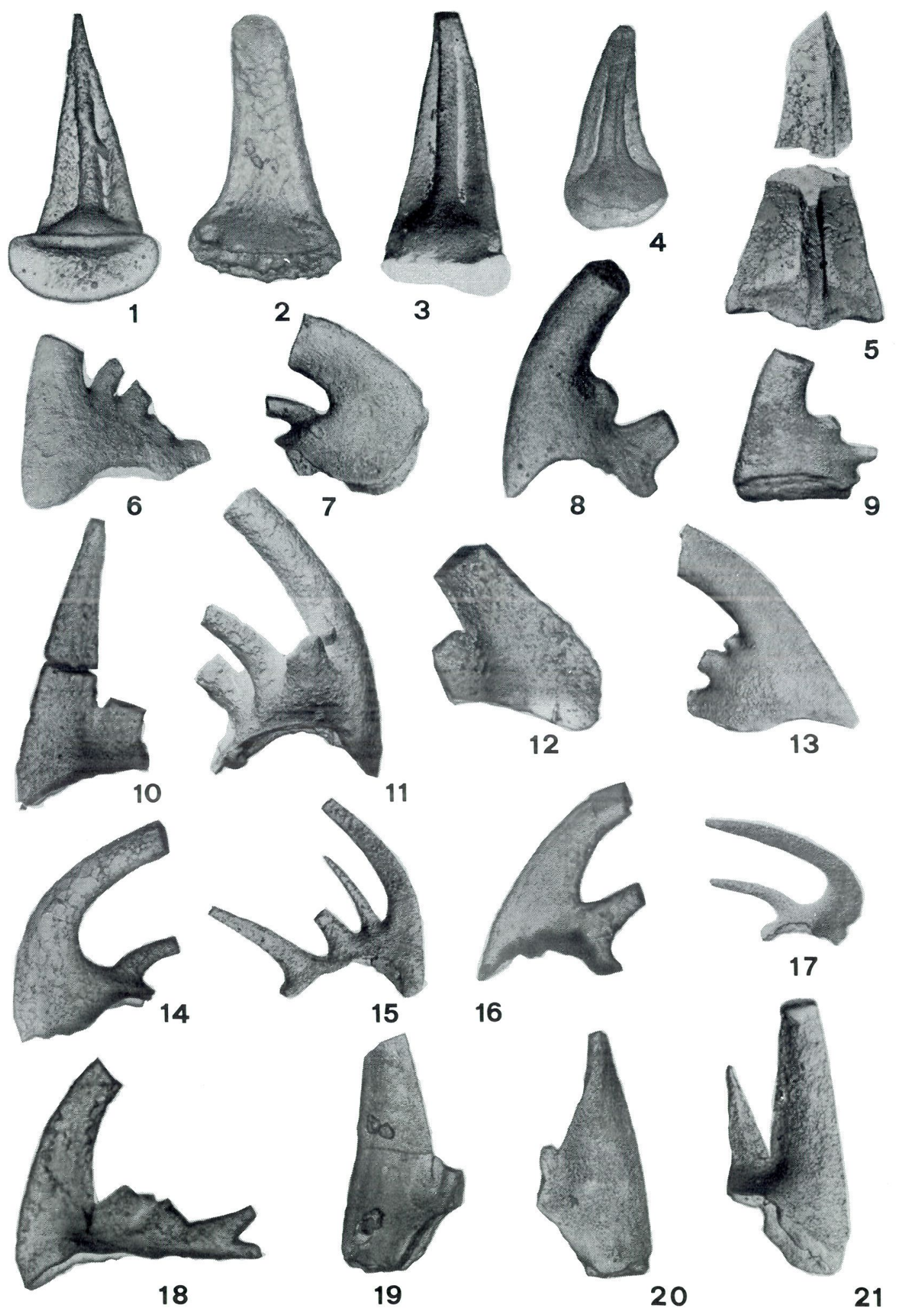


sensu Furnish, 1938, Oistodus? triangularis sensu Furnish, 1938 and Paltodus bassleri sensu Furnish, 1938 belonged to the same apparatus and formed a symmetry transition series.

Lindström (1977) proposed a different apparatus which he referred to the multielement genus Paltodus sensu Lindström, 1971. The apparatus comprised the formspecies $P$. bassleri, $P$. variabilis sensu Furnish, 1938, A. oneotensis, O.? triangularis and Oistodus inclinatus Branson \& Mehl sensu Furnish, 1938.

Ethington \& Clark (1981) disagreed with the two interpretations. Instead Ethington \& Clark (1981) found that $A$. oneotensis, O.? triangularis and $P$. bassleri (together with $P$. variabilis) represented three separate taxa, each one forming a symmetry transition series.

Landing \& Barnes (1981) mainly concurred with Sweet \& Bergström (1972) and they referred this complex apparatus to Utanconus? bassleri including also $P$. variabilis and Scolopodus sulcatus sensu Furnish, 1938.

We agree with Ethington \& Clark (1981) and consider three valid and different species are represented by the formspecies discussed above. Our material shows that the formspecies $A$. oneontensis and $S$. sulcatus are members of the same transition series. This transition series is characterized by elements which have an increasing lateral bend of the cusp. Consequently, we assign these element to the multielement genus Utahconus sensu Miller, 1980.

In the apparatus including the formspecies $P$. bassleri and $P$. variabilis the symmetry/asymm- etry is produced by a gradual torsion of the cusp of the element. The symmetrical and slightly asymmetrical elements $(=P$. variabilis $)$ have two costae, whereas the ultimate asymmetrical elements have only one costa $(=P$. bassleri $)$. A new generic name should be provided for this apparatus. At this stage we maintain the form generic name "Paltodus", because our specimens were obtained from loose blocks.

The apparatus composed by " $O$." triangularis sensu Furnish 1938 was discussed by Ethington \& Clark (1981).

Material - 24 specimens.

Repository - MGUH 16381-16383.

Genus Utahconus Miller, 1980.

Type species - Paltodus utahensis Miller, 1969.

Remarks - According to Miller (1980) the multielement genus Utahconus includes uni- to bicostate simple cones with a rounded base. The elements form a symmetry transition series in which the elements characteristically have a lateral bend of the cusp. Based on the Kap Clay specimens we expand the diagnosis of the multielement genus Utahconus to include species having the same apparatus plane, but with elements that have more than two costae.

Utahconus oneotensis (Furnish). P1. 2, Figs. 1114.

Synonymy

1938 Acodus oneotensis n. sp. - Furnish, p. 325, Pl. 42, Figs. 26-29.

PLATE 2.

Figs. 1-2. Clavohamulus sp. A. 1: antero-lateral view, Sample 479, MGUH 16359, ×200. 2: lateral view, Sample 471, MGUH 16358, $\times 125$.

Figs. 3-7. Cornuodus sp. A. 3: lateral view, Sample 477, MGUH 16377, $\times 150.4$ : lateral view, Sample 467, MGUH 16373, $\times 125.5$ : lateral view, Sample 464, MGUH 16375, x125. 6: lateral view, Sample 468, MGUH 16374, ×125. 7: lateral view, Sample 477, MGUH $16376, \times 150$.

Fig. 8. Drepanoistodus sp., lateral view, Sample 473, MGUH $16378, \times 125$.

Figs. 9-10. "Oistodus" triangularis Furnish. 9: lateral view, Sample 471, MGUH 16380, $\times 70$. 10: lateral view, Sample 466, MGUH $16379, \times 50$.

Figs. 11-14. Utahconus oneotensis (Furnish) 11: postero-lateral view, Sample 468, MGUH 16384, $\times 50$. 12: postero-lateral view, Sample 466, MGUH 16388, $\times 80.13$ : postero-lateral view, Sample 464, MGUH 16385, $\times 60.14$ : antero-lateral view, Sample 464, MGUH $16386, \times 60$.

Figs. 15-17. "Paltodus" bassleri Furnish. 15: postero-lateral view, Sample 466, MGUH 16383, ×100. 16: postero-lateral view, Sample 477, MGUH 16382, ×60. 17: lateral view, Sample 469, MGUH 16381, $\times 100$.

Figs. 18-19. Utahconus aff. $U$. utahensis (Miller). 18: Sample 468, MGUH 16390; 18a: lateral view, $\times 165$; 18b: antero-lateral view, $\times$ 175. 19: postero-lateral view, Sample 471, MGUH 16389, $\times 125$.

Figs. 20-22. Gen. et sp. indet. B. 20: postero-lateral view, Sample 468, MGUH 16394, $\times 125.21$ : lateral view, Sample 471, MGUH $16396, \times 125.22$ : postero-lateral view, Sample 477, MGUH 16395, $\times 115$.

Fig. 23. Gen. et sp. indet. C, postero-lateral view, Sample 464 , MGUH $16398, \times 200$. 

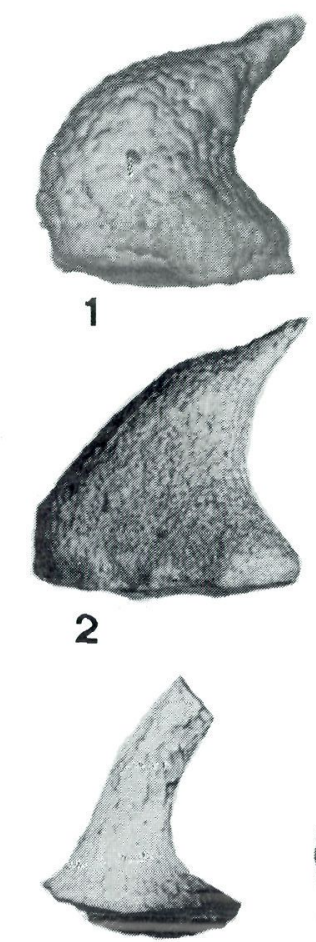

8

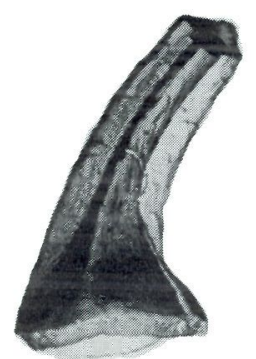

13

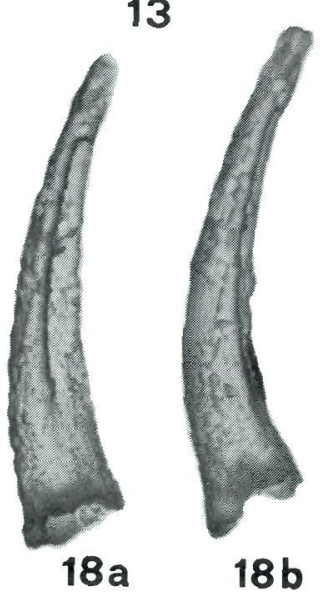

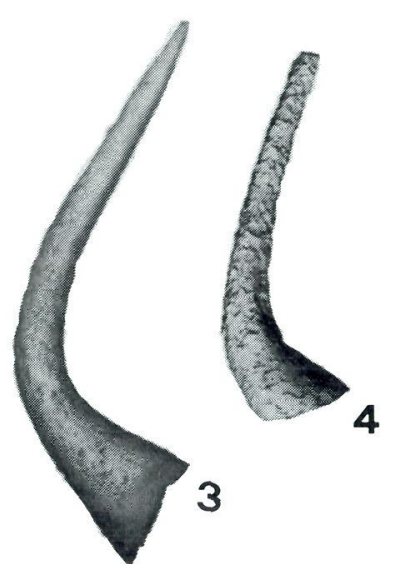

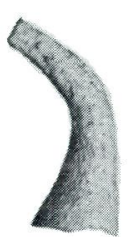

5

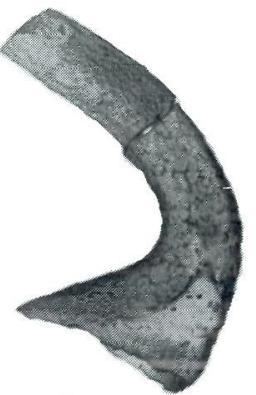

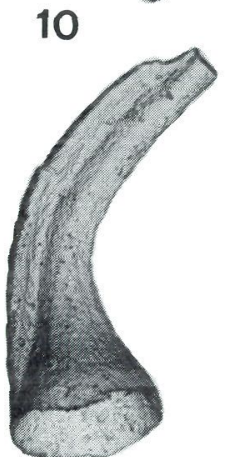

15
9

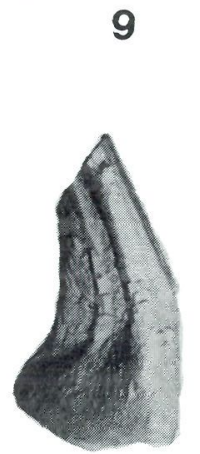

14
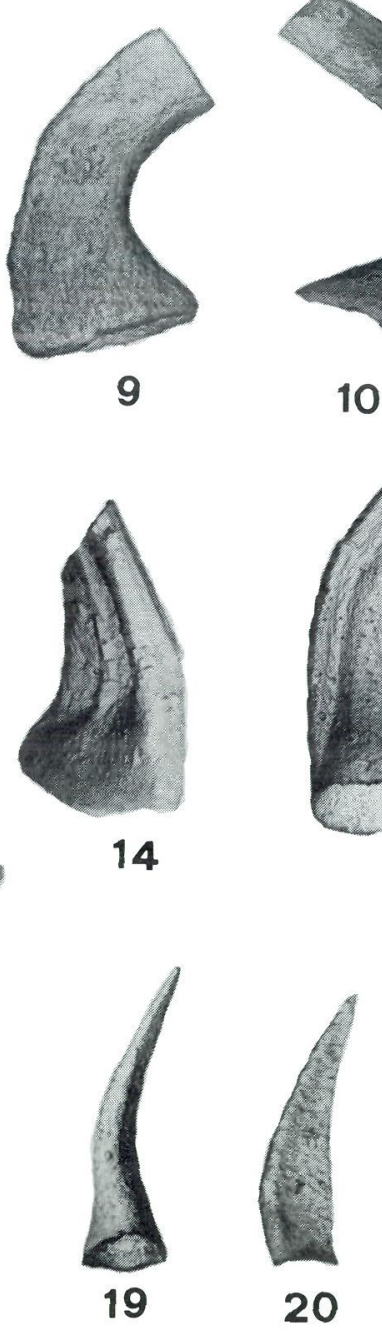
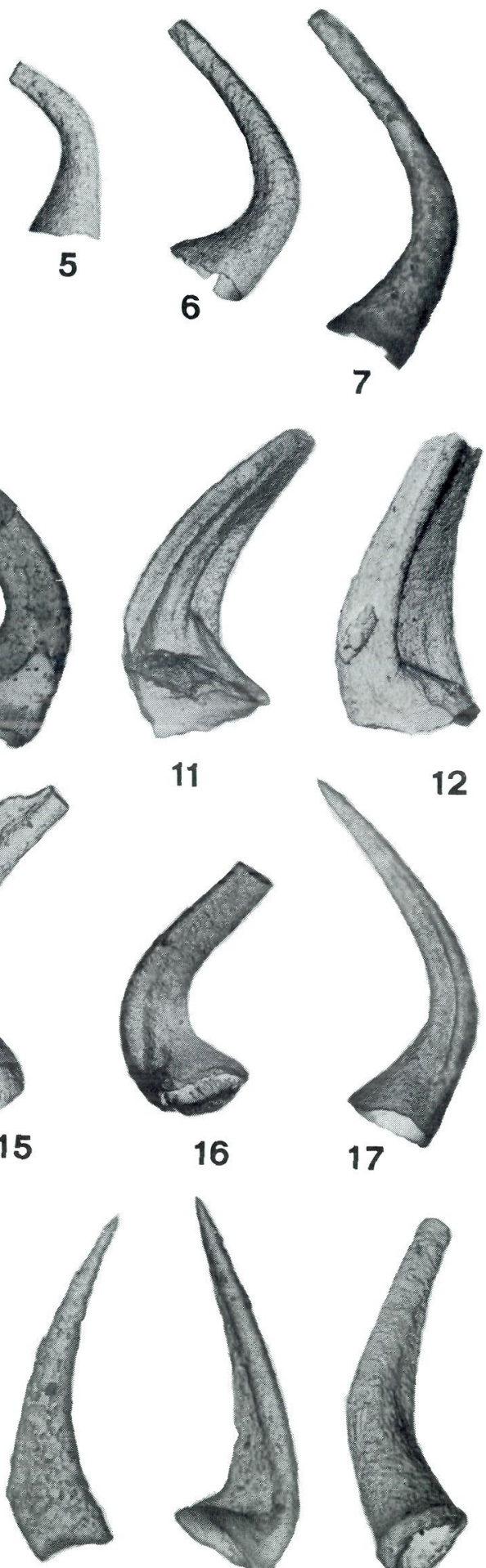

21
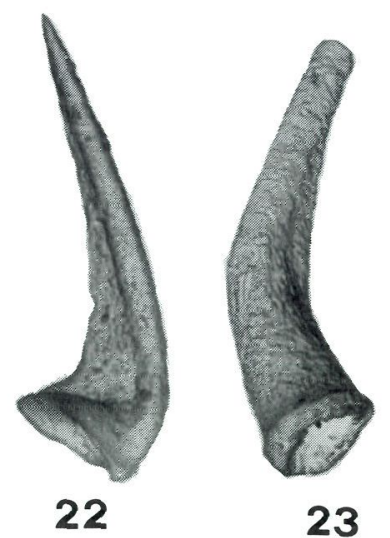
1938 Scolopodus sulcatus n.sp. - Furnish, p. 334, Pl. 41, Figs. 14-15.

1971 Acodus oneotensis Furnish - Ethington \& Clark, p. 72, P1. 1, Figs. 3, 6, 8.

1971 Acodus oneotensis Furnish - Jones, p. 44, P1. 1, Fig. 5a-c (only).

1977 Paltodus variabilis Furnish - Lindström, pp. 429-431 (pars), Paltodus-Pl. 1, Figs. 12, 15 (only).

1981 "Acodus" oneotensis Furnish - Ethington \& Clark, pp. 20-21, Pl. 1, Fig. 16.

1981 "Scolopodus" sulcatus Furnish - Ethington \& Clark, pp. 105-106, Pl. 12, Figs. 7, 8; Text-fig. 26.

1981 Utahconus? bassleri (Furnish) - Landing \& Barnes, pp. 1622-1624 (pars), Pl. 1, Figs. 3, 4, 7, 8, 10, 14, 18; Pl. 3, Figs. 18-21; Text-fig. 3: 7, 8, $11,13,40,41$ (only).

1982 Acodus oneotensis Furnish s.f. - Repetski, pp. 12-13, Pl. 2, Figs. 7, 8.

1982 Scolopodus sulcatus Furnish s.f. - Repetski, pp. 51-52, Pl. 24, Figs. 6, 8.

1983 Utahconus? bassleri (Furnish) - Landing, pp. 1181-1182 (pars), Fig. 10R.

Description - The elements of Utahconus oneotensis includes the formspecies Acodus oneotensis sensu Furnish, 1938 and Scolopodus sulcatus sensu Furnish, 1938. The elements have been fully described by Furnish (1938) and Repetski (1982), who also mentioned that the two formspecies were closely related.

Remarks - No perfectly, symmetrical elements have recorded from our material. Miller (1980), however, noted that true symmetrical elements of Utahconus are rare.

For other interpretations of the apparatus including $A$. oneotensis and $S$. sulcatus see Ethington \& Clark (1981) and this paper under "Paltodus" bassleri.

Material - 71 specimens.

Repository - MGUH 16384-16388.

Utahconus aff. $U$. utahensis (Miller). Pl. 2, figs. 18-19.

Description - The slender elements of $U$. aff. $U$. utahensis are almost straight and the cusp and the base are approximately of equal length. The aboral margin is circular in outline. The base is slightly concave anteriorly. The basal cavity is deep and the tip is located close to the anterior edge.

The white matter is confined to the upper two thirds of the cusp.

Only bicostate asymmetrical elements have been recorded.

Remarks - The Kap Clay specimens resemble Acodus sevierensis sensu Miller, 1969 (Pl. 63, Figs. 23-24) which has been included in the multielement species Utahconus utahensis by Miller (1980). The limited number of specimens available preclude a closer species indentification.

Material -7 specimens.

Repository - MGUH 16389-16390.

Gen. et sp. indet. A. Pl. 1, Figs. 19-21.

Description - Compound elements with a large, blade-like cusp and a short base carrying one or two fused laterally compressed denticles are referred to Gen. et sp. indet. A. The basal cavity is small. The cusp is erect, more or less twisted. The base is small and has an inner flare. The aboral margin is sinuous in lateral view.

The small basal cavity is triangular with concave edges. The tip is located in the posterior half of the cusp and it points upwards.

The white matter is concentrated in the cusp and denticle(s). The anterior part of the base has a cloudy appearance. Fine horizontal hyaline lines within the white matter of the cusp and of the anterior portion of the base are characteristic of these elements.

Material - 26 specimens.

Repository - MGUH 16391-16393.

Gen. et sp. indet. B. Pl. 2, Figs. 20-22.

Description - Gen. et sp. indet. B has a skeletal apparatus that comprises small, simple cones which are laterally compressed and form a symmetry transition series. The elements are proclined. The aboral edge is straight or slightly con- 
cave. the small basal cavity is triangular with an anteriorly located tip. White matter is confined to the cusp.

The symmetrical elements are broadly rounded anteriorly; posteriorly, they are narrow. The posterior margin is keeled. An anterior carina is present on each side of the elements. It extends from the base to the tip of the units. The crosssection of the base is subtriangular or droplike.

The asymmetrical elements are twisted and have en inner anterior carina. The base has an inner flare.

Material - 20 specimens.

Repository - MGUH 16394-16396.

Gen. et sp. indet. C. Pl. 2, Fig. 23.

\section{Synonymy}

?1981 Oneotodus? sp. A s.f. - Landing \& Barnes, pp. 1618, 1620, Pl. 1, Fig. 6; Text-fig. 3: 30.

Description - This species includes slender, proclined, symmetrical and asymmetrical elements with a circular to oval cross-section. The basal cavity is an asymmetrical triangle in lateral view. The tip is located close to the anterior edge. The aboral margin is characterized by a constricted rim.

The symmetrical element has a rounded anterior edge, a faint carina on each side and a sharp posterior edge. The base is rounded.

The asymmetrical element has a posterior keel on the cusp and an inner-lateral faint carina. The base is oval to rounded.

Material - 9 specimens.

Repository - MGUH 16397-16398.

Acknowledgements. We are grateful to the late Prof. Christian Poulsen, University of Copenhagen, for giving the access to the collections of J. C. Troelsen.

We acknowledge the Bartolommei Corp., Italy for comfort which facilitated the progress for this work.

The SEM pictures were taken at the Institute of Historical Geology and Palaeontology, University of Copenhagen. $\mathbf{H}$. Egelund drafted the figures.

\section{Dansk sammendrag}

J. C. Troelsen indsamlede i 1941 fossilholdige (Symphysurina sp. - Nedre Ordovicium) kalkstensprøver ved foden af Kap Clay, vestlige Nordgrønland. Conodonter fra disse prøver er relativt talrige (ialt 314 elementer kunne identificeres), og 20 multielement arter er repræsenteret. Flere af arterne er nye, men er introduceret informelt her, da prøverne ikke var indsamlet in situ.

Mikrofaunaen er karakteriseret af Cordylodus spp. og Utahconus oneotensis (Furnish), hvilket tillader en korrelation med den Nordamerikanske Midkontinent Fauna $\mathrm{C}$ eller Loxodus bransoni Interval (Nedre Canadien) og med den Balto-Skandinaviske Cordylodus angulatus Zone (Tremadocian).

Faunaindholdet $0 \mathrm{~g}$ den biostratigrafiske korrelation svarer til tidligere bestemmelser fra Cape Clay Formationen i arktisk Kanada og vestlige Nordgrønland, og de løse prøver stammer sandsynligvis fra Cape Clay Formationen ved Kap Clay. Den beskrevne conodont fauna er derfor representativ for Nedre Ordovisium i de pảgxldende områder.

\section{References}

Bagnoli, G., Barnes, C. R. \& Stevens, R. K. (in press): Cambro-Ordovician conodonts from the Cow Head Group, western Newfoundland. - Can. J. Earth Sci.

Christie, R. L. 1967: Bache Peninsula, Ellesmere Island, Arctic Archipelago. - Mem. geol. surv. Can., 347: 1-63.

Dawes, P. R. 1971: The North Greenland fold belt and environs. - Bull. geol. Soc. Denmark, 20: 197-239.

Dawes, P. R. 1976: Precambrian to Tertiary of Northern Greenland. In: A. Escher and W. Stuart Watt (eds.) Geology of Greenland: 248-303.

Druce, E. C. \& Jones, P. J. 1971: Cambro-Ordovician conodonts from the Burke River Structural Belt Queensland. Australian Bureau of Min. Res., Bull. 110: 1-159.

Epstein, A. G., Epstein, G. B. \& Harris, L. D. 1977: Conodont Color Alteration - an Index to Organic Metamorphism - Geol. Surv. Prof. Pap., 995: 1-27.

Ethington, R. L. \& Clark, D. L. 1971: Lower Ordovician conodonts in North America. - Geol. Soc. America, Mem., 127: 63-82.

Ethington, R. L. \& Clark, D. L. 1981: Lower and Middle Ordovician conodonts from the Ibex Area Western Millard County, Utah. - Brigham Young Univ. Geol. Studies, 28: 1-155.

Fåhræus, L. E. 1966: Lower Viruan (Middle Ordovician) conodonts from the Gullhögen quarry, southern central Sweden. - Sver. Geol. Unders. C, 610: 1-40.

Furnish, W. M. 1938: Conodonts from the Prairie du Chien (Lower Ordovician) beds of the Upper Mississippi Valley. -J. Pal., 12: 318-340.

Henriksen, N. \& Peel, J. S. 1975: Cambrian-Early Ordovician stratigraphy in south-western Washington Land, western North Greenland. - Rapp. Grønlands geol. Unders., 80: 17-22.

Hurst, J.M. \& Surlyk, F. 1983: Depositional environments along a carbonate ramp to slope transition in the Silurian of Washington Land, North Greenland. - Can. J. Earth Sci., 20: 473-499.

Jeppsson, L. \& Merrill, G. K. 1982: How best designate absolete taxonomic names and concepts: examples among conodonts. - J. Pal., 56: 1489-1493.

Jones, P. J. 1971: Lower Ordovician conodonts from the Bonaparte Gulf Basin and the Daly River Basin, northwestern Australia. - Australian Bureau of Min. Res., Bull., 117: $1-80$. 
Koch, L. 1929a: Stratigraphy of Greenland, - Meddr. Grønland, 73: 205-320.

Koch, L. 1929b: The geology of the south coast of Washington Land. - Meddr. Gronland, 73: 1-39.

Koch, L. 1932: Map of North Greenland, 1:300.000. Copenhagen.

Koch, L. 1933: The geology of Inglefield Land. - Meddr. Gronland. 73(2).

Kurtz, V.E. 1977: Trans-Cratonic correlation of early Ordovician conodont Faunas B and $\mathrm{C}$ between Northwest Greenland and Western United States. - Abstr. Progr. geol. soc. am. (North-Central Sec.): 618.

Landing, E. 1983: Highgate Gorge: Upper Cambrian and Lower Ordovician continental slope deposition and biostratigraphy, northwestern Vermont. - J. Pal., 57: 11491187.

Landing, E. \& Barnes, C. R. 1981: Conodonts from the Cape Clay Formation (Lower Ordovician), southern Devon IsJand, Arctic Archipelago. - Can. J. Earth Sci., 18: 16091628.

Lindström, M. 1955: Conodonts from the lowermost Ordovician strata of South-Central Sweden. - Geol. Fören. Stockholm Förh., 76: 517-604.

Lindström, M. 1971: Lower Ordovician Conodonts of Europe. - Geol. Soc. America, Mem., 127: 21-61.

Lindström, M. 1977: In: Ziegler (ed.) Catalogue of Conodonts, 3.

Löfgren, A. 1978: Arenigian and Llanvirnian conodonts from Jämtland, northern Sweden. - Fossils and Strata, 13: 1129.

Miller, J.F. 1969: Conodont fauna of the Notch Peak Limestone (Cambro-Ordovician), House Range, Utah. - J. Pal., 43: 413-439.

Miller, J.F. 1980: Taxonomic revision of some Upper Cambrian and Lower Ordovician conodonts with comments to their evolution. - Univ. Kansas, Paleont. Contrib., 99: 139.

Müller, K. J. 1959: Kambrische Conodonten. - Zeitschr. Deutsch. Geol. Ges., 11: 434-485.

Müller, K. J. 1973: Late Cambrian and Early Ordovician Conodonts from Northern Iran. - Geol. Surv. Iran, Rep., 30: 177.

Pander, C. H. 1856: Monographie der Fossilen Fische des Silurischen Systems der Russisch-Baltischen Gouvernements. - K. Akad. Wiss. St. Petersburg: 1-91.

Poulsen, C. 1927: The Cambrian, Ozarkian and Canadian faunas of Northwest Greenland. - Meddr. Grønland, 70: 233343.

Repetski, J. 1982: Conodonts from the El Paso Group (Lower Ordovician) of westernmost Texas and southern New Mexico. - New Mexico Bureau Mines \& Mineral Resources, Mem., 40: 1-117.

Sergeeva, S. P. 1962: Conodonts from the Lower Ordovician of the Leningrad region. - Akad. Nauk. SSSR, Palaeont. Journ., 1963: 93-108 (in Russian).

Stouge, S. 1977: A Lower Ordovician conodont fauna from the Cape Clay Formation, NW Greenland. - Abst. Progr. geol. Soc. Am. (North-Central Section): 656.

Troelsen, J. C. 1950: Contributions to the geology of Northwest Greenland, Ellesmere Island and Axel Heiberg Island. Meddr. Grønland, 149: 1-86.

van Wamel, W. A. 1974: Conodont biostratigraphy of the Upper Cambrian and Lower Ordovician of North-Western Öland, south-eastern Sweden. - Utrecht Micropal. Bull., 10: $1-126$

Viira, V. 1970: Conodonts of the Varangu Member (Estonian Upper Tremadoc). - Eesti NSV Tead. Akad., Toim., Keem. Geol., 19: 224-233 (in Russian).

Viira, V. 1974: Ordovician conodonts of the Baltic: 1-142. Tallinn (in Russian). 